\title{
Ceci N’est Pas Une île.
}

\author{
SÉBASTIEN ROY \\ University of British Columbia
}

\begin{abstract}
Using the conceptual paradigm of the map and the territory, the following essay investigates the underlaying mechanisms that pushes China to "build" a series of islands in the Spratly Archipelago, a highly contested region of the South China Sea.
\end{abstract}

The great wall of sand is a project of land reclamation undertaken by the Government of the People's Republic of China since late 2013 in South China Sea. The intention is to strengthen the territorial claims in a highly contested area involving China, Malaysia, the Philippines, Taiwan, and Vietnam. They consist of seven highly militarized man-made island part of the Spratly Archipelago. The U.S. Pentagon estimates the amount of reclaimed land as: 2,900 acres for China, 80 acres for Vietnam, 70 acres for Malaysia, 14 acres for the Philippines and 8 acres for Taiwan. ${ }^{1}$ China states that the construction is for "improving the working and living conditions of people stationed on these islands" and that, "China is aiming to provide shelter, aid in navigation, weather forecasts and fishery assistance to ships of various countries passing through the sea." 2 Only two years ago most of these islands did not exist. How did they appear there, and why would a country create land masses miles away from large urban centres and financial hubs? Such land construction practises have been seen before where countries expand their territory through engineered lands out of necessities, though here the aspirations of such construction and their consequences are unprecedented. In order to get built, China must first locate pre-existing rock formations, land masses or coral reefs usually submerged only a few metres under water over which a vast amount of sand is pumped using a fleet of dredgers; ships designed to pick up and move materials from the seafloor. These dredgers use large tubes with cutting attachments at the end to grind up material on the seafloor and suck it up. From there, the material is carried through pipes and discharged on top of reefs, rocks, and other existing formations. For submerging the atolls, a total area of 13.5 square kilometers was pumped from the surroundings; 40 or 50 million cubic meters of sand and coral resulting in significant and irreversible damage to the environment. ${ }^{3}$ These islands are an attempt from China to lay claim in one of the most important areas of ocean in the world. On one hand for its rich natural resources: 11 billion barrels of oils, 190 trillion cubic feet of natural gas, and $10 \%$ of the world's fisheries. But also for its strategic location: $30 \%$ of global shipping trades flows through it ( $\$ 3$ trillion in trade each year $)^{4}$ and is surrounded by the booming economic markets of South East Asia. As a result, the more island a country can claim, the more territory and subsequently resources it can gain. Currently, five countries lay claims in this extremely important body of water. Most countries base their claims on the United Nations Convention on the Law of the Sea (UNCLOS) stating that a country's territorial water extends 200 miles off their shore, giving them exclusive right to all the resources and trades. ${ }^{5}$ China, on the other hand, argues it has a historical claim to the South China Sea dating back to naval exploration in the 15th century. They marked their territory using a very confusing boarder called 'The 9 Dash Line', encompassing at the same time $90 \%$ of the South China Sea.

Between reality and fiction, between natural and war machines, these man-made islands question the dialectic between architecture and the landscape, between representation and reality, between the map and the territory.

Traditionally, the map is a demonstration of a fundamental human instinct, a desire to understand our surroundings and to position oneself within it. Though in the current situation, the map becomes an operative tool on our world. It is a representation of what the world should be viewed as, a materialization of a society's deepest ideal. Fundamentally the map can never reproduce a terrain in its entirety, as a consequence it combines the real with the representational, the natural with the ideological. Map-making is not a naive act, nor is it an objective science, rather it is a tool that can be used to claim, obtain or exercise power and imperial domination. Maps thus become a depiction which reflects attitudes and values of the society that produced them. Historically, China has used maps, in times of both peace and war, as educational tools, to guide, instruct and edify, but also as a tangible means of maintaining the emperor's territorial claims locally as much as globally.

The Polish-American scholar, Alfred Korzybski tried to define this dual opposition between the map and the territory. He explains the difference in abstraction between the reality and our semantic representation. The verbal world (map) is not the extensional world (territory). The symbol is not the thing symbolized. His conclusions in Science and Sanity (1933) are :

1) The words are not what they represent - the map is not the territory;

2) A word does not represent all the facts - the map does not represent the entire territory

3) Language is self-referential - the map is self-referential. ${ }^{6}$ 


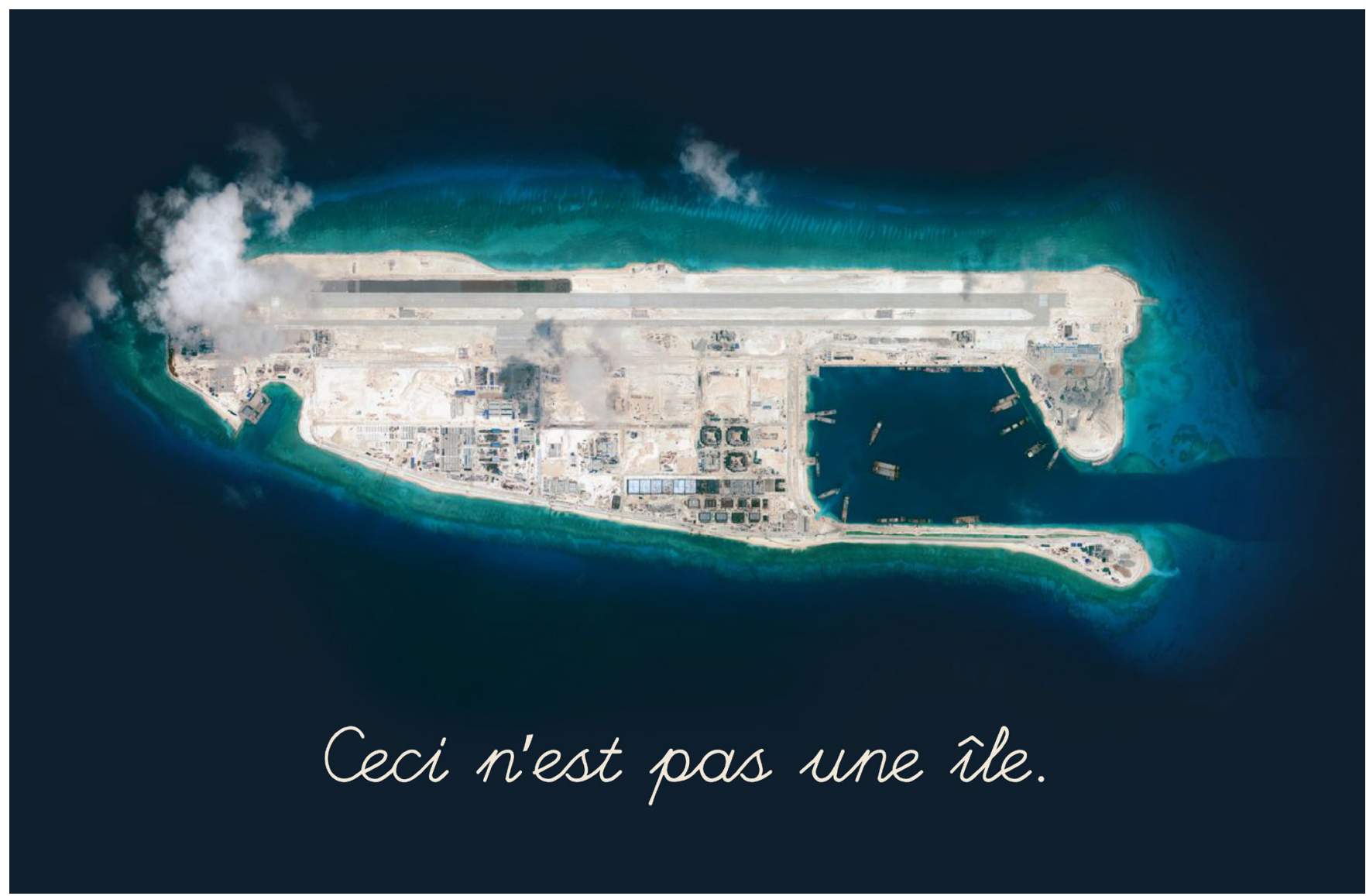

Figure 1: Fiery Cross is not an island, Author (2017)

So we say the map is different from the territory. But what is the territory? As Gregory Bateson, English anthropologist puts it: "Operationally, someone went out with a retina or a measuring stick and made a representation which was put on paper. What is on the paper map is a representation of what was in the retinal representation of the man who made the map; and as you push the question back, what you find is an infinite regress, and infinite series of maps. The territory never gets in at all." What happens when the territory does not exist in the first place? In the current situation, in the South China Sea, there is no territory to be found, no reality as a reference, though the map still expresses a reality which is not there. Could it be that this paradigmatic representation of the Map-Territory relation does not apply anymore? Jean Baudrillard allows us to better understand what is happening here with his definition of 'Hyperreality'. "Today abstraction is no longer that of the map, the double, the mirror, or the concept. Simulation is no longer that of a territory, a referential being, or a substance. It is the generation by models of a real without origin or reality: a hyperreal. The territory no longer precedes the map, nor does it survive it. It is nevertheless the map that precedes the territory-precession of simulacra-that engenders the territory."

Thus, the Map is the Territory and the Territory is the Map. If the map represents what China sees as their territory, they will make it a reality so it corresponds to their ideal. The artificial islands are the map and the territory at the same time. They are the ideal and the reality collapsed into a man-made piece of land. This reversal of the dialectic Map-Territory has unprecedented impacts on the way we perceive the world, organize and construct it. We can see the same paradigmatic reversal in the domain of virtual reality, where computers used to be an abstraction of a reality now become generator of realities. Computer generated realities become the basis on which we construct the tangible and physical world. The emergence of new technologies and the act of mapping the globe through satellite imagery brought an Age of Un-discovery. An age where every mistake from the un-precise and culturally driven act of mapping have been adjusted. Phantom territories that were fictitiously mapped for empirical reasons, or by pure mistake, are being corrected now that our capacity to map the world in its entirety have reached perfection and a quasi-undeniable fidelity. As opposed to the Age of Discovery, the Age of Un-discoveries corrects cartographic errors and deliberate mistakes. Thus the subjectivity once carried by the map is being expelled from it. The creation of islands by China is the first act as we enter the Age of Production; the production of the territory as a tool for subjectivity and imperialism. The map has lost its capacity to carry subjectivity; it is, in turn, the territory who is now taking on and receiving this role. By creating and shaping its own islands, we can conclude that China is making of the territory, 


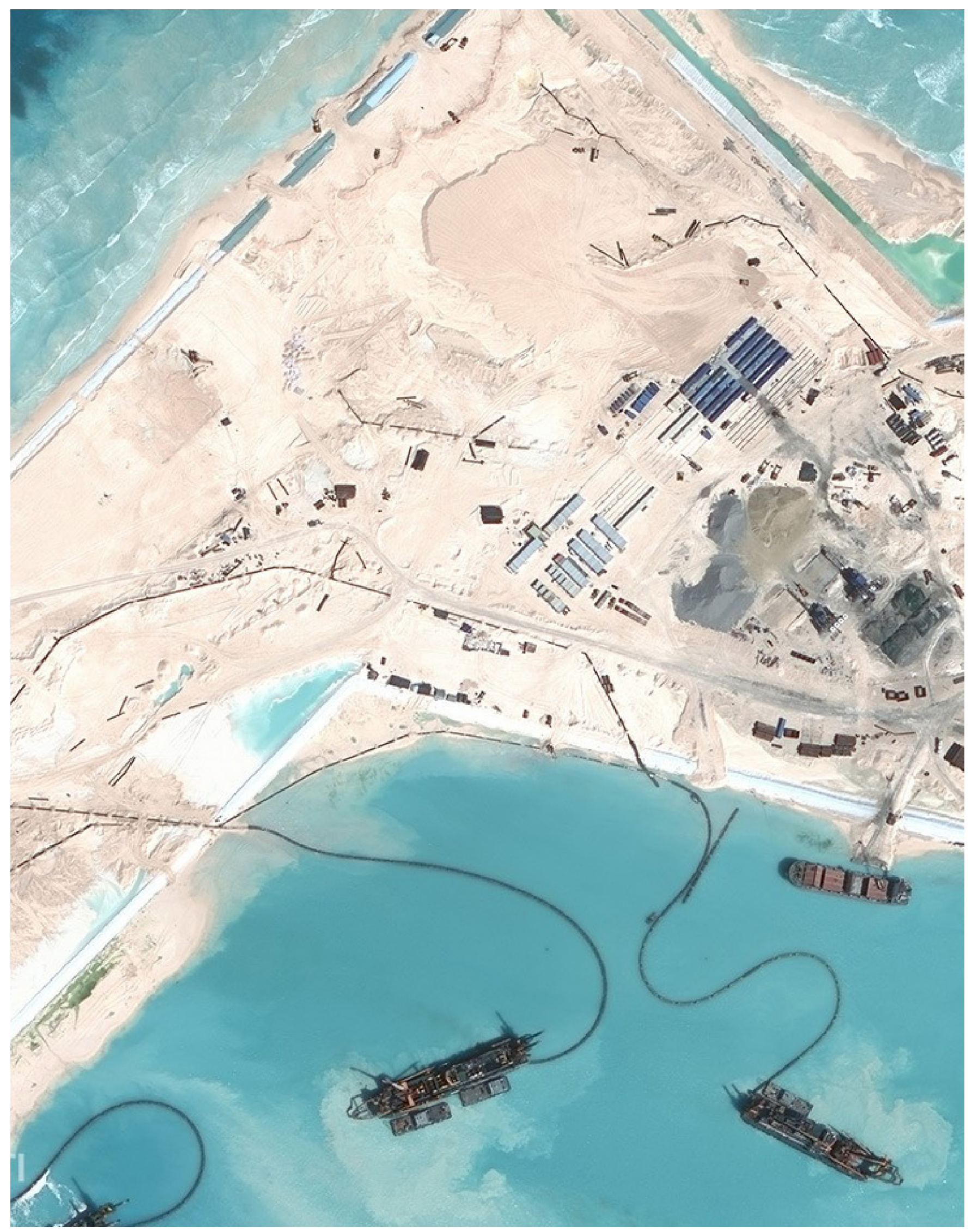

Figure 2: Aerial photograph taken from a military aircraft shows alleged on-going reclamaition by China (2016) 
the map. The map, by achieving unprecedented levels of realism, has no longer the capacity of carrying conceptual abstraction of a reality, it therefore can no longer hold up to the subjective qualities that it once had, it is now on the territory that one needs to operate in order to express an ideal. Thus, the map and the territory today are being hybridized, interchangeable and cross-referential; the territory becomes the map and the map becomes the territory in a perpetual cascading loop.

\section{ENDNOTES}

1 "China has reclaimed 3,200 acres in the South China Sea, says Pentagon". The Guardian. 13 May 2016. https://www.theguardian.com/world/2016/may/13/ pentagon-report-china-reclaimed-3200-acres-south-china-sea. Retrieved March 12, 2017

2 "China building 'great wall of sand' in South China Sea". BBC. 1 April 2015. http://www.bbc.com/news/world-asia-32126840. Retrieved March 05, 2017.

3 Lubold, Gordon. "Pentagon Says China Has Stepped Up Land Reclamation in South China Sea". The Wall Street Journal. 20 August 2015. https://www.wsj. com/articles/pentagon-says-china-has-stepped-up-land-reclamation-insouth-china-sea-1440120837. Retrieved August 21, 2017.

4 Fisher, Max. "The South China Sea: Explaining the Dispute". The New York Times. 14 July 2016. https://www.nytimes.com/2016/07/15/world/asia/southchina-sea-dispute-arbitration-explained.html. Retrieved August 21, 2017.

5 United Nations, "United Nations Convention on the Law of the Sea (UNCLOS)", December 1982.

6 Korzybski, Alfred. "Science and Sanity, An Introduction to Non-Aristotelian Systems and General Semantics", Institute of General Semantic : New York, 1933.

7 Bateson, Gregory. "Steps to an Ecology of Mind", Chandler Pub. Co.: London, 1972. 461

8 Beaudrillard, Jean. “Simulacres et Simulation”, Galilé : Paris, 1981. 10

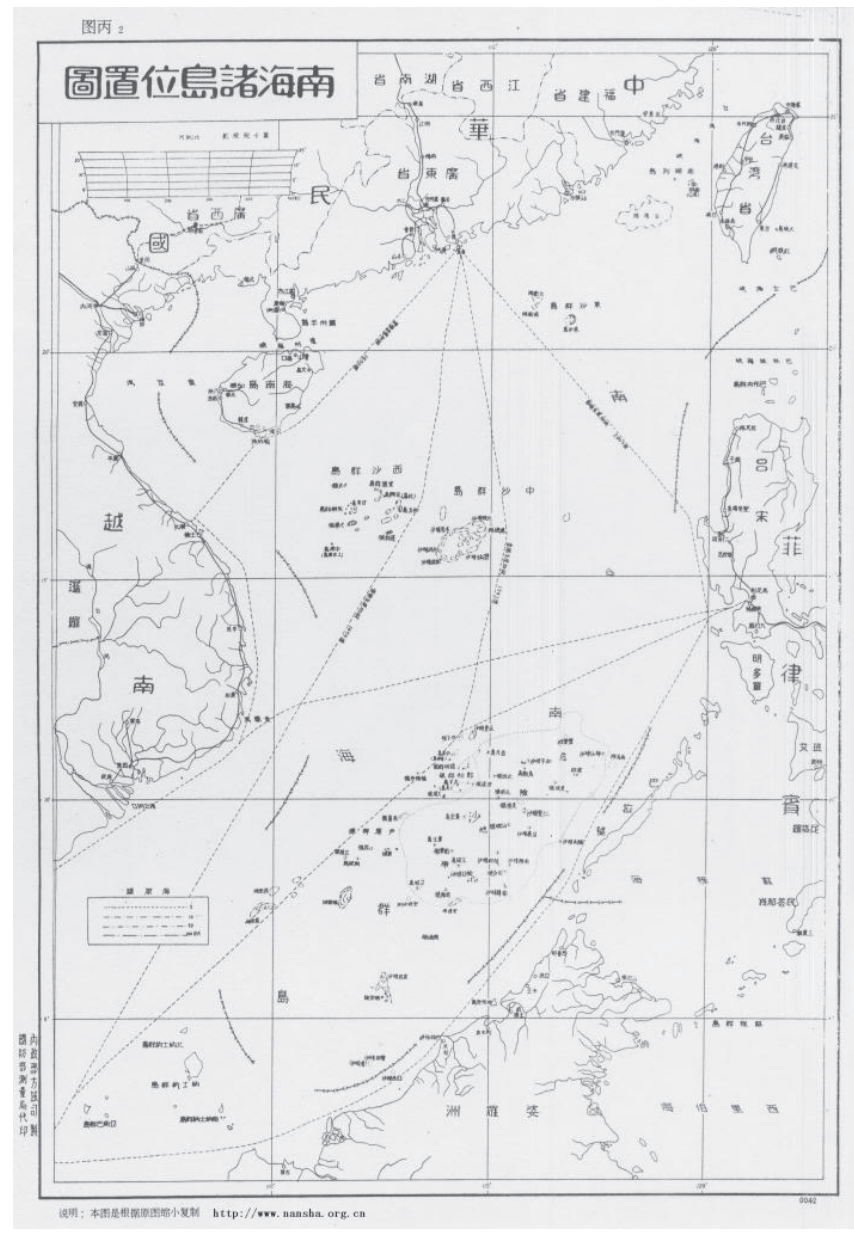

Figure 3: China's 1947 map depicting the "nine-dash line". 